\title{
APLIKASI SISTEM PAKAR UNTUK MENDIAGNOSA GANGGUAN JARINGAN LAN BERBASIS ANDROID DI SEKOLAH KEMURNIAN JAKARTA
}

\author{
Sutrisno ${ }^{1}$ \\ Dedy Prasetya Kristiadi ${ }^{2}$ \\ Dedeh Supriyanti ${ }^{3}$ \\ Dosen STMIK RAHARJA ${ }^{1,2,3}$ \\ Jl. Jendral Sudirman No. 40, Modernland, Tangerang ${ }^{1,2,3}$ \\ E-mail: $\underline{\text { sutrisno@ raharja.info }}{ }^{1}$, dedy.prasetya@ raharja.info ${ }^{2}, \underline{\text { dedeh@ }}^{\text {raharja.info }}{ }^{3}$
}

\begin{abstract}
ABSTRAK
LAN merupakan jaringan di dalam sebuah gedung atau suatu area yang luas wilayahnya berukuran sampai beberapa kilometer. Jangkauan lan yang luas menyebabkan kesulitan dalam mencari kerusakan atau kesalahan yang menyebabkan gangguan pada lan. Oleh karena itu dibutuhkan suatu teknologi yang memungkinkan manusia mengetahui penyebab dari gangguan-gangguan yang terjadi pada jaringan tersebut. Sistem pakar (expert system) adalah program penasehat berbasis komputer yang mencoba meniru proses berpikir dan pengetahuan dari seorang pakar dalam menyelesaikan masalah-masalah spesifik. Dengan sistem pakar, seseorang bisa menganalisa dan mengatasi masalah-masalah yang terjadi pada jaringan LAN.
\end{abstract}

Kata kunci : LAN,Sistem Pakar,android

\begin{abstract}
LAN(Local area network) is a network within a building or an area of a size up to several kilometers. The wide reach of the lan causes difficulties in finding the damage or errors that cause disturbance to the lan. Therefore required a technology that allows human beings to know the cause of the disturbances that occur in the network. The expert system is a computer-based advisory program that tries to imitate the thinking and knowledge processes of an expert in solving specific problems. With expert system, one can analyze and solve problems that occur in LAN network.
\end{abstract}

Keywords : LAN, Expert System,Android

\section{PENDAHULUAN}

Di jaman era globalisasi saat ini, teknologi dan informasi perkembangannya sangat pesat. Teknologi berfungsi membantu manusia melakukan pekerjannya secara efektif dan efisien dan mempermudah hidup manusia, dengan kemajuan teknologi dan informasi kegiatan yang sebelumnya dikerjakan secara manual sudah dapat dikerjakan dengan komputer yang tentunya lebih bisa menghemat waktu dan biaya serta kegiatannya lebih efektif. Kecerdasan Buatan (Artificial Intelligenceatau AI) didefinisikan sebagai kecerdasan entitas ilmiah. Kecerdasan diciptakan dan dimasukkan ke dalam suatu mesin (komputer) agar dapat melakukan pekerjaan seperti yang dapat dilakukan manusia.. Dengan adanya kecerdasan 
buatan, diharapkan tidak menutup kemungkinan hanya dengan data pengetahuan yang terbatas, sebuah komputer dapat berpikir seperti manusia dalam menghadapi masalah. LAN merupakan jaringan di dalam sebuah gedung atau suatu area yang luas wilayahnya berukuran sampai beberapa kilometer. Jangkauan lan yang luas menyebabkan kesulitan dalam mencari kerusakan atau kesalahan yang menyebabkan gangguan pada lan. Oleh karena itu dibutuhkan suatu teknologi yang memungkinkan manusia mengetahui penyebab dari gangguan-gangguan yang terjadi pada jaringan tersebut. Sistem pakar (expert system) adalah program penasehat berbasis komputer yang mencoba meniru proses berpikir dan pengetahuan dari seorang pakar dalam menyelesaikan masalah-masalah spesifik. Dengan sistem pakar, seseorang bisa menganalisa dan mengatasi masalah-masalah yang terjadi pada jaringan LAN. SEKOLAH KEMURNIAN yang terletak di Jakarta Barat sering terjadi gangguan pada jaringan LAN yang mengakibatkan terhambatnya pekerjaan sehingga banyak waktu yang terbuang dan terbatasnya staff di bagian IT Infrastruktur yang ruang lingkup kerjanya hingga mencapai ke sekolah cabang yang masih berada di lingkungan Jakarta Barat.

\section{METODE PENELITIAN}

\section{Konsep Dasar Pakar}

\section{Definisi Pakar}

Seorang pakar atau ahli (human expert) adalah individu yang memiliki kemampuan pemahaman yang baik dari suatu masalah tertentu (Tolle, 2008).

\section{Basis Pengetahuan (Knowledge Base)}

Basis pengetahuan berisi mengenai pengetahuan-pengetahuan dalam penyelesaian masalah, tentu saja dalam domain tertentu. Ada dua bentuk pendekatan basis pengetahuan yang sangat umum digunakan, yaitu : Penalaran berbasis aturan (Ruled Based Reasoning) Basis pengetahuan direpresentasikan dengan menggunakan aturan berbentuk IF-THEN. Bentuk ini digunakan apabila kita memiliki sejumlah pengetahuan pakar pada suatu permasalahan tertentu. Penalaran berbasis kasus (Case Based Reasoning)Basis pengetahuan akan berisi solusi-solusi yang telah dicapai sebelumnya, kemudian akan diturunkan suatu solusi untuk keadaan yang terjadi sekarang.

\section{Konsep Dasar Aplikasi Android}

\section{Definisi Aplikasi}

Aplikasi adalah program siap pakai yang dapat digunakan untuk menjalankan perintahperintah dari pengguna aplikasi tersebut dengan tujuan mendapatkan hasil yang lebih akurat sesuai dengan tujuan pembuatan aplikasi tersebut, aplikasi mempunyai arti yaitu pemecahan masalah yang menggunakan salah satu tehnik pemrosesan data aplikasi yang biasanya berpacu pada sebuah komputansi yang diinginkan atau diharapkan maupun pemrosesan data yang diharapkan. Pengertian aplikasi secara umum adalah alat terapan yang difungsikan secara khusus dan terpadu sesuai kemampuan yang dimilikinya aplikasi merupakan suatu perangkat komputer yang siap pakai bagi user. Aplikasi dapat digolongkan menjadi beberapa kelas, antaralain: Perangkat lunak perusahaan (enterprise),Perangkat lunak infrastruktur 
perusahaan,Perangkat lunak informasi kerja.Perangkat lunak media dan hiburan.Perangkat lunak pendidikan.Perangkat lunak pengembangan media.Perangkat lunak rekayasa produk.

\section{Definisi Aplikasi Android}

Aplikasi Android ditulis dalam bahasa pemrograman java. Kode java dikompilasi bersama dengan data file resource yang dibutuhkan oleh aplikasi, dimana prosesnya dipackage oleh tools yang dinamakan apt tools ke dalam paket android sehingga menghasilkan file dengan ekstensi apk. File apk itulah yang kita sebut dengan aplikasi, dan nantinya dapat di install di perangkat mobile. (Nazruddin Safaat H., 2012:9). Ada empat jenis komponen pada aplikasi Android yaitu : Activitie,Service,Broadcast Receiver,Content Provider

\section{Konsep Dasar Sistem Pakar}

\section{Definisi Sistem Pakar}

Menurut Martin dan Oxman dalam Kusrini (2010:11), “sistem pakar (Expert System) merupakan sistem berbasis komputer yang menggunakan pengetahuan, fakta, dan teknik penalaran dalam memecahkan masalah yang biasanya hanya dapat dipecahkan oleh seorang pakar dalam bidang tersebut. Sistem pakar adalah aplikasi berbasis komputer yang digunakan untuk menyelesaikan masalah sebagaimana yang dipikirkan oleh pakar. Contoh lain, seorang dokter ahli jantung adalah seorang yang mempunyai keahlian dan pengalaman dalam mengobati dan menyembuhkan pasiennya, psikolog adalah orang yang ahli dalam memahami kepribadian seseorang, dan lain-lain. (kusrini, 2009). Sistem pakar biasa disebut dengan knowledge-based system. Sistem ini bekerja dengan pengetahuan (knowledge) dan metode analisis yang telah didefinisikan terlebih dahulu oleh pakar yang sesuai dengan bidang keahliannya. Sistem pakar bisa juga dikatakan sebagai keahlian yang dipindahkan dari pakar ke suatu komputer. Pengetahuan ini kemudian disimpan dalam komputer. Pada saat user menjalankan komputer untuk mendapatkan informasi, sistem pakar menanyakan fakta-fakta dan dapat membuat penalaran sampai pada sebuah kesimpulan. Dengan sistem pakar ini, orang awam pun dapat menyelesaikan masalahnya atau hanya sekedar mencari suatu informasi berkualitas yang sebenarnya hanya dapat diperoleh dengan bantuan para ahli di bidangnya. Sistem pakar ini juga dapat membantu aktivitas para pakar sebagai asisten yang mempunyai pengetahuan yang dibutuhkan.

\begin{tabular}{|c|c|c|}
\hline $\begin{array}{c}\text { Taktor } \\
\text { Tuner: Avaluziliay }\end{array}$ & $\begin{array}{c}\text { Pakar } \\
\text { Hari kerja }\end{array}$ & $\begin{array}{l}\text { Sistem Pakar } \\
\text { Scrian saat }\end{array}$ \\
\hline Grognalis & Iukaliteilentu & Dinila sajd \\
\hline Kеашагаב & Tidak ke:zralik:II & Deppal discali \\
\hline Perishable: Dapat habis & Ys & Tidak \\
\hline Horomatu: & Varuixl & Kousisitm \\
\hline Kexepultun & Verulel & Konsisleru \& Letrih Cepul \\
\hline Bivya & Tugg: & Tejaygkau \\
\hline
\end{tabular}

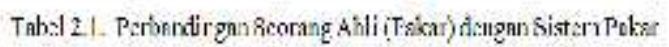




\section{Struktur Dasar Sistem Pakar}

Struktur dasar sistem pakar terdiri dari knowledge base, working memory, dan inference engine. Berikut merupakan gambar perbandingan antara human expert (Gambar 2.1) dan expert system (Gambar 2.2). Terlihat bahwa sistem pakar mengadopsi cara berpikir human expert sehingga menghasilkan sebuah keputusan atau solusi.

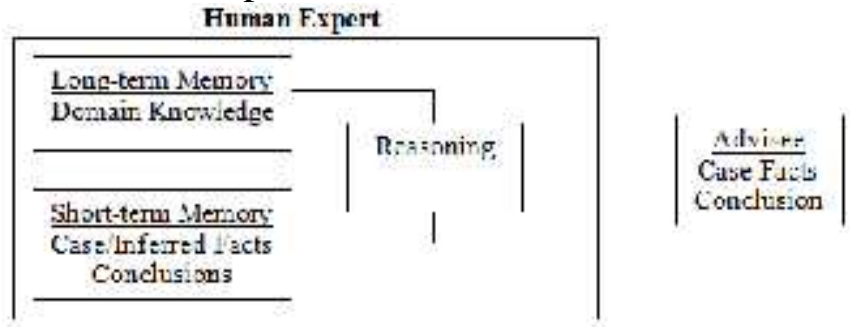

Gambar 2.1. Human Expert Problem Solving

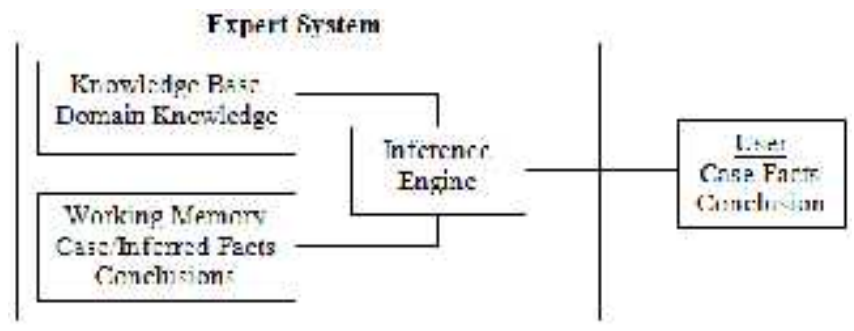

Gambar 2.2. Expert System Problem Solving

\section{A. Metode Inferensi}

Macam-macam metode inferensi, yaitu :

Forward Chaining (Pelacakan ke Depan)Menurut Helmi kurniawan dan Iwan Fitrianto Rahmad (2012:191), "forward chaining adalah mempergunakan himpunan kaidah kondisi aksi. Forward chaining adalah suatu strategi pengambilan keputusan yang dimulai dari bagian premis (fakta) menuju konklusi (kesimpulan akhir) (kusrini, 2009). 2. Backward Chaining (Pelacakan ke Belakang) Backward chaining adalah suatu strategi pengambilan keputusan dimulai dari pencarian solusi dari kesimpulan kemudian menelusuri fakta-fakta yang ada hingga menemukan solusi yang sesuai dengan faktafakta yang diberikan pengguna. (kusrini, 2009).

\section{B. UML (Unified Modeling Language)}

\section{Definisi UML}

Menurut Nugroho (2010:6), "UML (Unified Modeling Language) adalah perangkat lunak yang berparadigma "berorientasi objek". Pemodelan (modeling) sesungguhnya digunakan untuk penyederhanaan permasalahan-permasalahan yang kompleks sedemikian rupa sehingga lebih mudah dipelajari dan dipahami.

\section{Diagram UML}

Berikut ini adalah diagram UML menurut Henderi (2009:6) yaitu: Use Case Diagram.Use Case Diagram secara grafis menggambarkan, interaksi secara sistem, sistem eksternal dan pengguna. Dengan kata lain use case diagram secara grafis mendeskripsikan siapa yang akan menggunakan sistem dan dalam cara apa pengguna (user) mengharapkan 
interaksi dengan sistem itu. Use case secara naratif digunakan untuk secara tekstual menggambarkan sekuensi langkah-langkah dari tiap interaksi. Class Diagram Menggambarkan struktur object sistem. Diagram ini menunjukan class diagram yang menyusun sistem dan hubungan antara class object tersebut. Sequence Diagram Secara grafis menggambarkan bagaimana objek berinteraksi satu sama lain melalui pesan pada sekuensi sebuah use case atau operasi. State Chart Diagram Digunakan untuk memodelkan behaviour objek khusus yang dinamis. Diagram ini mengilustrasikan siklus hidup objek berbagai keadaan yang dapat diasumsikan oleh objek dan event-event (kejadian) yang menyebabkan objek dari satu state ke state yang lain. Activity Diagram Secara grafis untuk menggambarkan rangkaianaliran aktivitas baik proses bisnis maupun use case. Activity Diagram dapat juga digunakan untuk memodelkan action yang akan dilakukan saat operasi dieksekusi, dan memodelkan hasil dari action tersebut.

\section{Konsep Dasar Jaringan Komputer Local Area Network (LAN)}

Sesuai dengan namanya, LAN berhubungan dengan area network yang berukuran relatif kecil. Oleh sebab itu, LAN dapat dikembangkan dengan mudah dan mendukung kecepatan transfer data cukup tinggi. (Iwan Sofana, 2012:113). Ada 4 bentuk dasar LAN atau disebut Topologi fisik LAN, yaitu: Topologi Bus, Topologi Star,Topologi Ring, Topologi Mesh atau Fully-Mesh

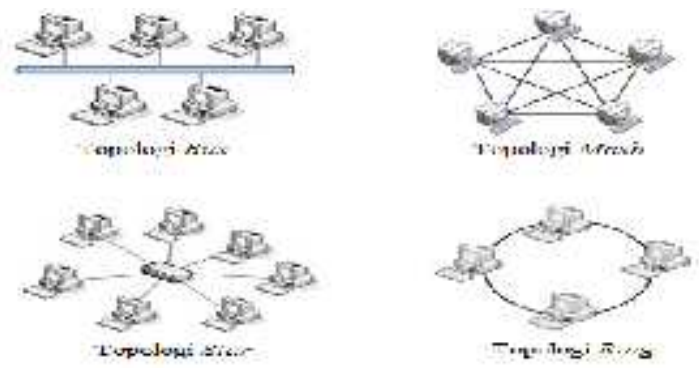

a. Topologi Bus

Gambar 2.5. Diagram topologi

Topologi Bus menggunakan sebuah kabel backbone dan semua host terhubung secara langsung pada kabel tersebut.

b. Topologi Star

Topologi Star menghubungkan semua komputer pada sentral atau konsentrator. Biasanya konsentrator adalah sebuah hub atau switch.

c. Topologi Ring

Topologi Ring menhubungkan dengan host lainnya hingga membentuk ring (lingkaran tertutup).

d. Topologi Mesh atau Fully-Mesh

Topologi mesh menghubungkan setiap komputer secara point-to-point. Artinya semua komputer akan saling terhubung satu-satu sehingga tidak dijumpai ada link yang putus. Topologi ini biasanya digunakan pada lokasi yang kritis, seperti instalasi nuklir. Topologi mesh juga merupakan jenis topologi yang digunakan oleh Internet. Di mana dapat dijumpai banyak jalur (path) menuju sebuah lokasi. Biasanya tiap lokasi dihubungkan oleh router. 


\section{Konsep Dasar Android}

Definisi Android Menurut Nazruddin Safaat H.(2012:1), “Android adalah sebuah sistem operasi untuk perangkat mobile berbasis linux yang mencakup sistem operasi, middleware dan aplikasi”. Android bisa digunakan oleh setiap orang yang ingin menggunakannya pada perangkat mereka. Android menyediakan platform terbuka bagi para pengembang untuk menciptakan aplikasi mereka sendiri yang akan digunakan untuk bermacam peranti bergerak.

\section{Rancangan Prosedur Sistem Berjalan}

\section{Prosedur Sistem Berjalan Pada Use Case Diagram}

Pada penelitian ini digunakan program Unified Modelling Language (UML) untuk menggambarkan proses sistem yang berjalan saat ini sesuai prosedur dengan use case diagram, yaitu sebagai berikut :

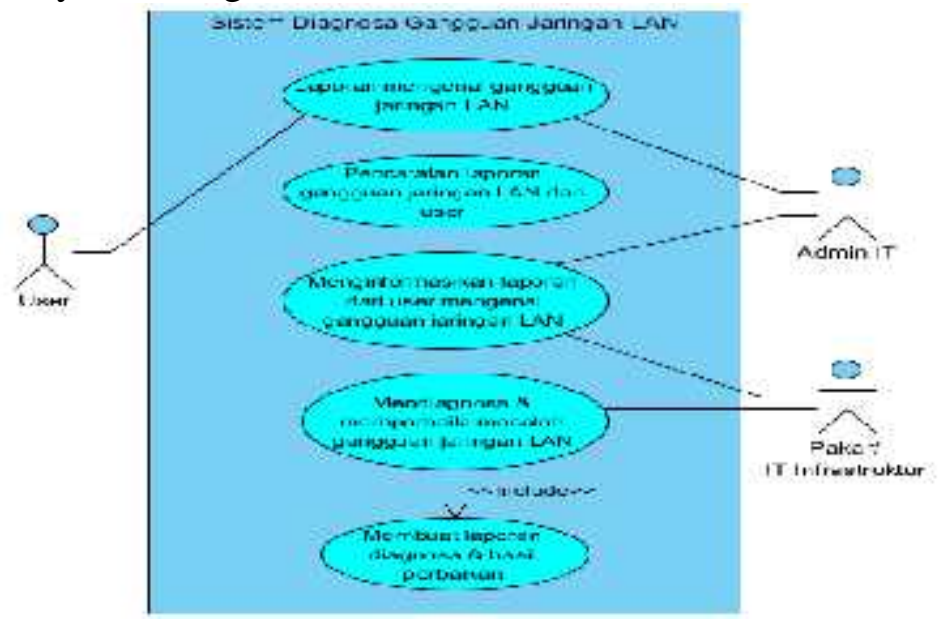

Gambar 3.7.Use Case Diagram Sistem yang Berjalan

use case diagram yang berjalan yaitu sebagai berikut :

1) User memberikan laporan terjadi gangguan jaringan LAN.

2) Admin IT menerima dan mencatat laporan dari user mengenai gangguan jaringan LAN .

3) Admin IT menginformasikan atau meneruskan laporan dari user ke IT Infrastruktur.

4) Pakar/IT Infrastruktur menerima laporan dari Admin IT.

5) Pakar/IT Infrastruktur mendiagnosa dan memperbaiki masalah gangguan LAN, kemudian membuat laporan dari hasil diagnosa tersebut. 


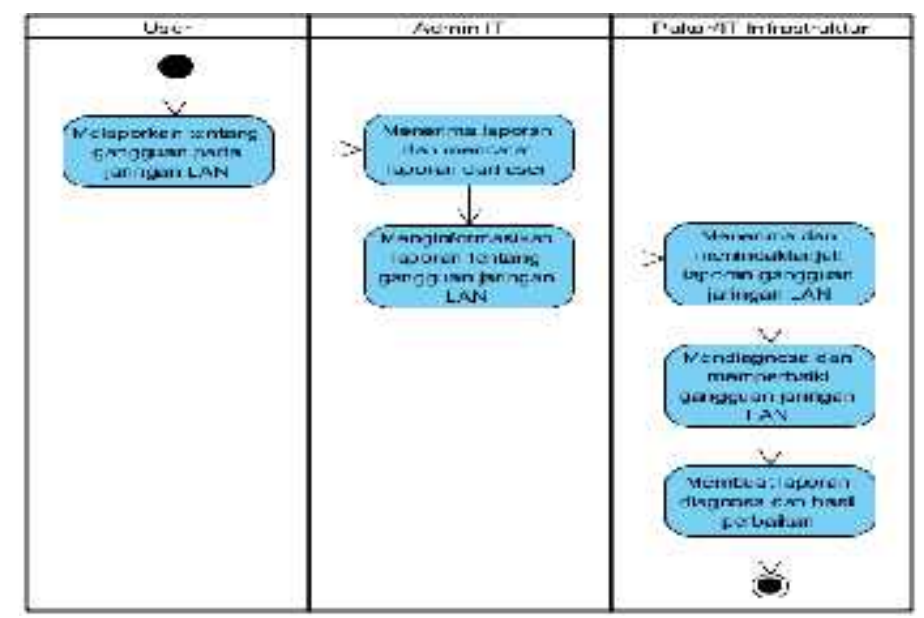

Gambar 3.8. Activity Diagram Sistem yang Berjalan

User melaporkan tentang gangguan pada jaringan LAN, Menerima laporan dan mencatat laporan dari user, Menginformasikan laporan tentang gangguan jaringan LAN, Menerima dan menindaklanjuti laporan gangguan jaringan LAN, Mendiagnosa dan memperbaiki gangguan jaringan LAN, Membuat laporan diagnosa dan hasil perbaikan.

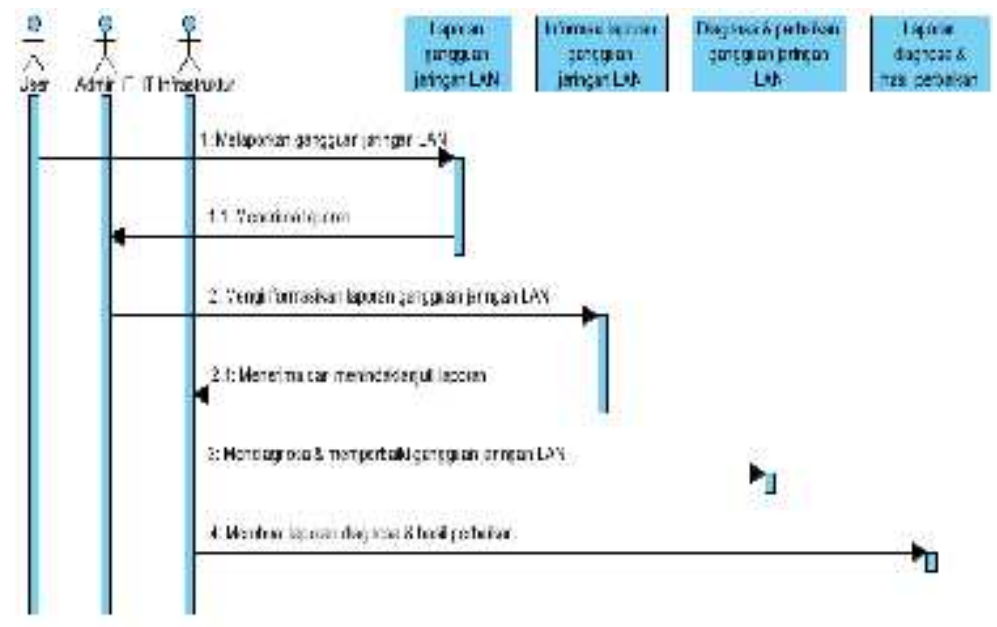

\section{Gambar 3.9. Sequence Diagram Sistem yang berjalan}

Laporan gangguan jaringan LAN, Informasi laporan gangguan jaringan LAN, Diagnosa dan perbaikan gangguan jaringan LAN, Laporan diagnosa dan hasil perbaikan. Bisa menjadi alat komunikasi antar objek yang memuat informasiinformasi tentang aktifitas yang terjadi.

\section{Analisa Sistem Yang Berjalan}

Analisis sistem merupakan bagian yang sangat penting karena apabila terjadi kesalahan dalam tahap ini, maka akan mengakibatkan kesalahan pada tahap selanjutnya. Pada bagian analisis sistem ini akan dibahas tentang Metode analisa sistem dan Analisa masukan, Analisa proses, Analisa keluaran. 


\section{Metode Analisa Sistem}

Analisis sistem dilakukan menggunakan Metode Forward Chaining (Pelacakan ke depan). Forward chaining adalah suatu strategi pengambilan keputusan yang dimulai dari bagian premis (fakta) menuju konklusi (kesimpulan akhir). Dengan metode forward chaining, semua data dan aturan akan ditelusuri untuk mendapatkan informasi dari gangguan-gangguan yang dialami.

\section{Konfigurasi Sistem Berjalan}

a) Spesifikasi Hardware

1) Processor : Intel(R) Core(TM) i3-3217U

2) Monitor : Generic PnP Monitor

3) RAM : 2 GB

4) Harddisk : $500 \mathrm{~GB}$

b) Spesifikasi Software

1) Windows 7Ultimate 64-bit

2) Microsoft Office 2007

\section{Permasalahan yang Dihadapi dan Alternatif Pemecahan Masalah}

\section{Permasalahan yang dihadapi}

Berdasarkan hasil analisa dan observasi yang telah dilakukan, maka permasalahan yang ada adalah sebagai berikut: User yang kurang paham mengenai masalah gangguan-gangguan pada jaringan LAN dan solusinya. Kurangnya jumlah tenaga kerja di sub bagian IT Infrastruktur, sehingga jika terjadi masalah pada perangkat komputer ataupun terjadi gangguan pada jaringan LAN di bagian/department lain, maka dapat menyebabkan waktu kerja menjadi tidak efisien karena banyak waktu yang terbuang hanya untuk menunggu Staff sub bagian IT Infrastruktur datang untuk memperbaiki masalah yang terjadi.

\section{Solusi}

\section{Alternatif Pemecahan Masalah}

Setelah mengamati dan meneliti dari beberapa permasalahan yang ada dari sistem yang berjalan, terdapat alternatif pemecahan dari permasalahan yang dihadapi antara lain :

a) Membangun sistem yang dibutuhkan oleh user dengan menggunakan aplikasi berbasis visual karena aplikasi yang berbasis visual sudah familiar dikalangan instansi masyarakat.

b) Membangun suatu aplikasi sistem pakar diagnosa gangguan-gangguan pada jaringan LAN yang berbasiskan mobile (Android), sehingga user dapat mengoperasikan aplikasi sistem pakar tersebut dengan mudah dalam pendiagnosaan gangguan-gangguan jaringan LAN dan solusinya secara cepat hanya dengan menggunakan smartphone berbasis android. 
Berdasarkan beberapa alternatif pemecahan masalah di atas penulis melakukan suatu kajian untuk permasalahan maka perlu dibangun aplikasi sistem yang berbasis Android karena banyak keuntungan yang diperoleh antara lain : 1)Agar user dapat dengan mudah dalam pendiagnosaan gangguan secara cepat. 2)Dapat menjalankan aplikasi berbasis Android ini dimanapun dan kapanpun.3)Tidak memerlukan spesifikasi smartphone yang tinggi untuk dapat menggunakan aplikasi berbasis Android. 4)Memanfaatkan pengembangan smartphone yang begitu pesat merupakan salah satu alternatif pemecahan masalah yang kedua yaitu dengan membangun aplikasi yang bisa membantu user untuk mengetahui gejala gangguan pada jaringan LAN beserta solusinya.

\section{User Requirement}

\section{Final Draft Elisitasi}

Final draft elisitasi merupakan bentuk akhir dari tahap-tahap elisitasi yang dapat dijadikan acuan dan dasar untuk membangun Aplikasi Sistem Pakar Diagnosa Gangguan Jaringan LAN Berbasis Android.

\section{Tabel 3.4. Final Draft Elisitasi}

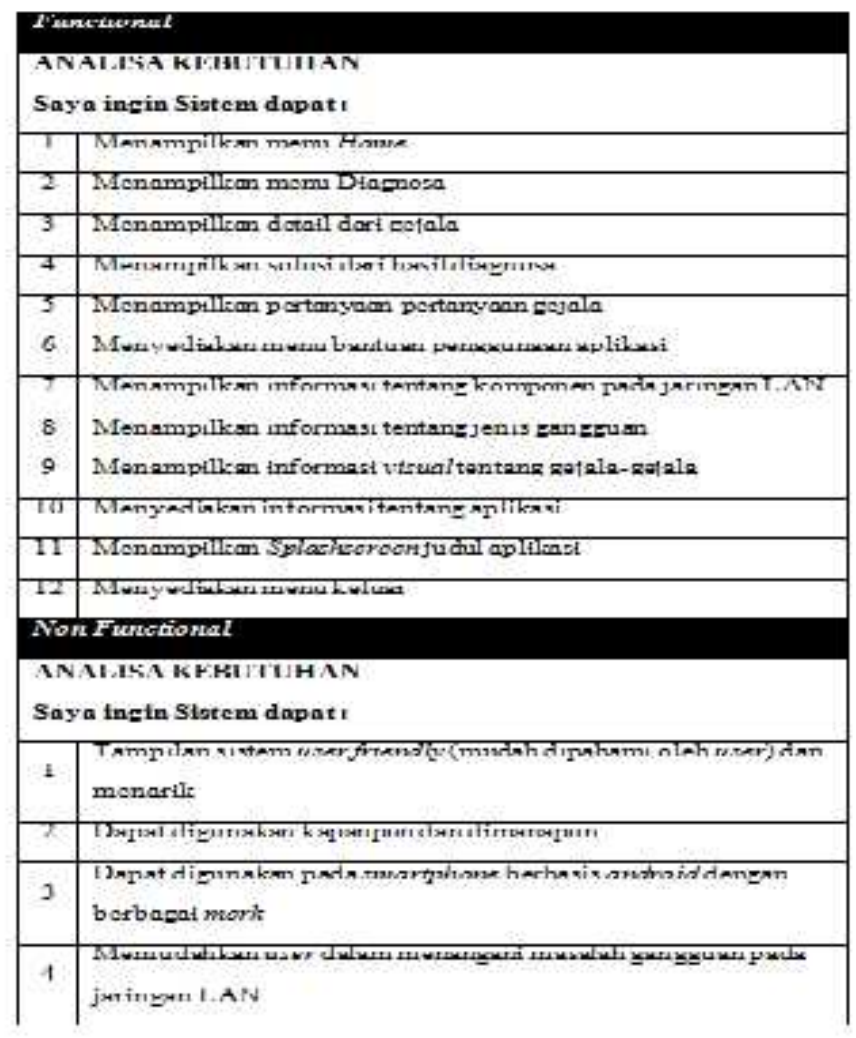




\section{Rancangan Sistem Usulan}

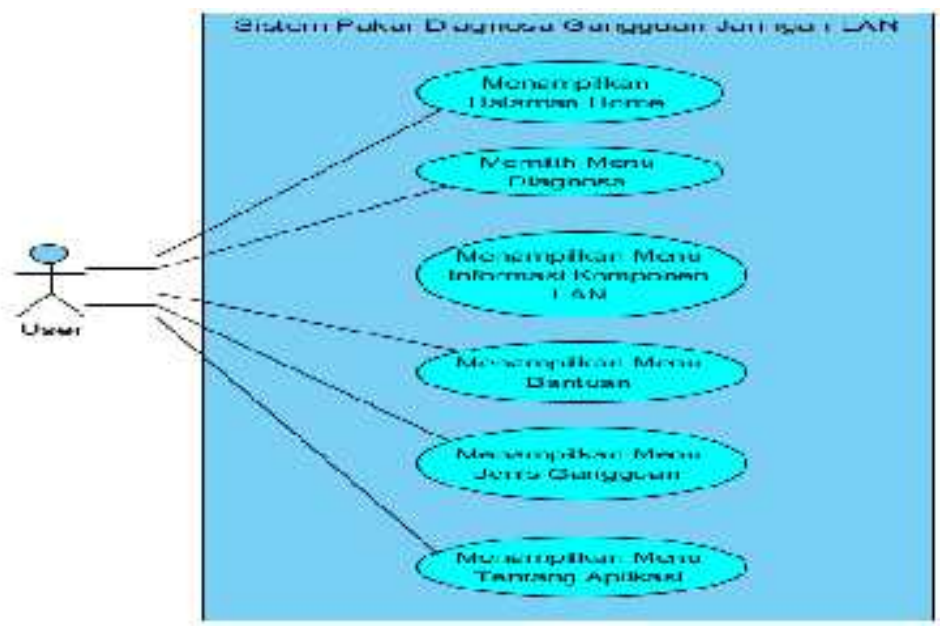

Gambar 4.1Use Case Diagram Sistem yang diusulkan

Berdasarkan gambar Use Case Diagram diatas terdapat sistem untuk mendiagnosa gangguan jaringan LAN yang diusulkan.

Diagram yang diusulkan yaitu sebagai berikut :

\section{a. Activity Diagram Diagnosa}

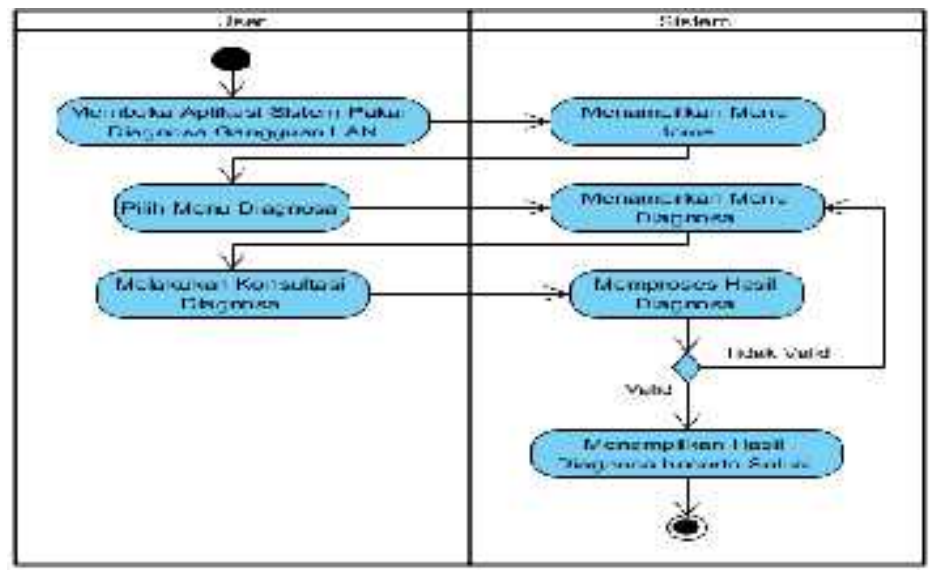

Gambar 4.2. Activity Diagram Diagnosa

Membuka aplikasi sistem pakar diagnosa gangguan LAN, Menampilkan menu home, Pilih menu diagnosa, Menampilkan menu diagnosa, Melakukan konsultasi diagnosa, Memproses hasil diagnosa, Menampilkan hasil diagnosa beserta solusi. 


\section{b. Activity Diagram Jenis Gangguan}

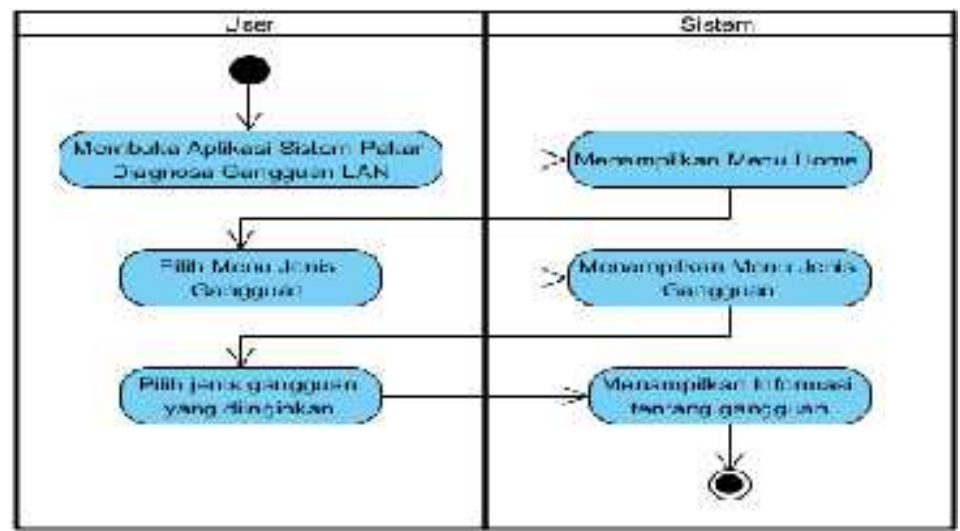

Gambar 4.3. Activity Diagram Jenis gangguan

Membuka aplikasi sistem pakar diagnosa gangguan LAN, Menampilkan menu home, Pilih menu jenis gangguan, Menampilkan menu jenis gangguan, Pilih jenis gangguan yang diinginkan, Menampilkan informasi tentang gangguan.

\section{c. Activity Diagram Bantuan}

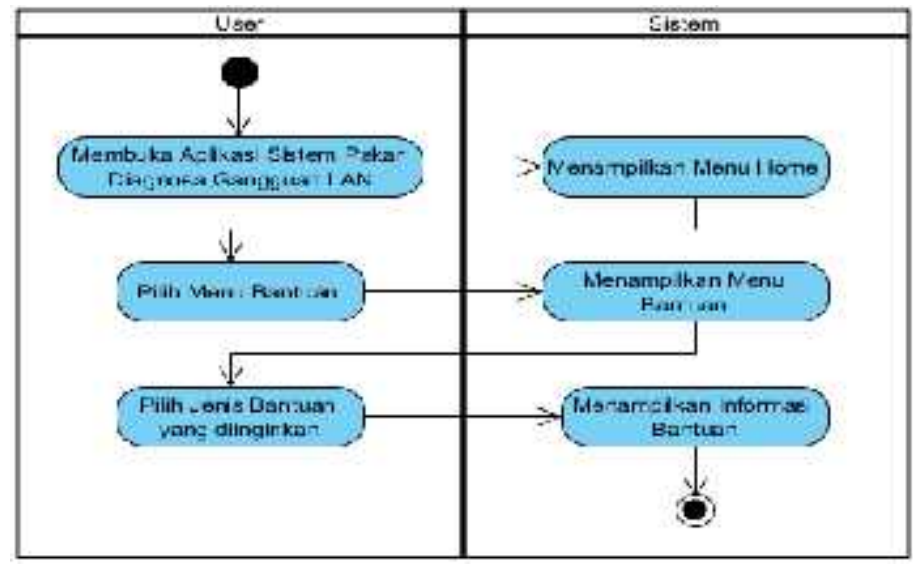

Gambar 4.4. Activity Diagram Bantuan

Membuka aplikasi sistem pakar diagnosa gangguan LAN, Menampilkan menu home, Pilih menu bantuan, Menampilkan menu bantuan, Pilih jenis bantuan yang diinginkan, Menampilkan informasi bantuan. 


\section{d. Activity Diagram Informasi Komponen Jaringan LAN}

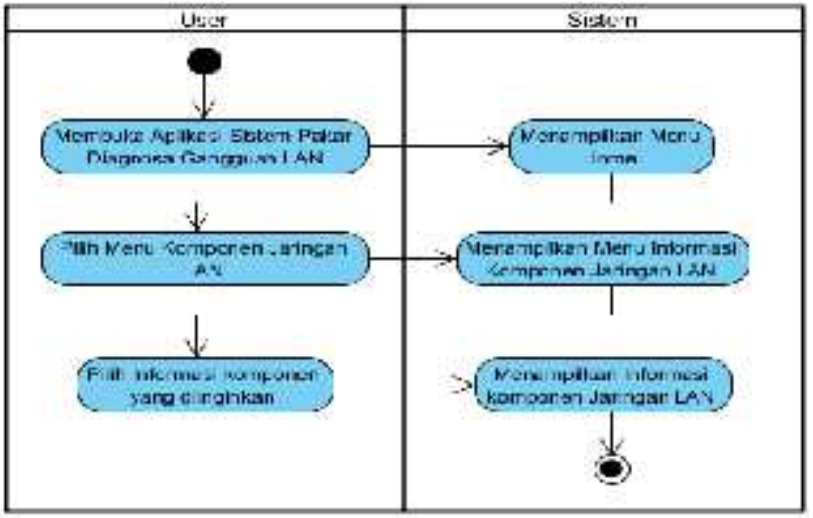

Gambar 4.5. Activity Diagram Komponen Jaringan LAN

Membuka aplikasi sistem pakar diagnosa gangguan LAN, Menampilkan menu home, Pilih menu komponen jaringan LAN, Menampilkan menu informasi komponen jaringan LAN, Pilih informasi komponen yang diinginkan, Menampilkan informasi komponen jaringan LAN.

\section{e. Activity Diagram Tentang Aplikasi}

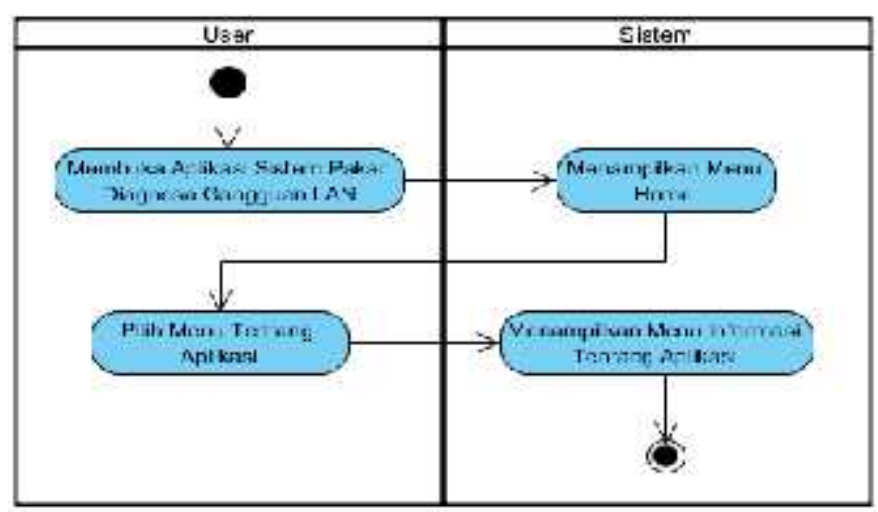

Gambar 4.6. Activity Diagram Tentang Aplikasi

Membuka aplikasi sistem pakar diagnose gangguan LAN, Menampilkan menu home, Pilih menu tentang aplikasi, Menampilkan menu informasi tentang aplikasi.

\section{Sistem yang diusulkan}

\section{Flowchart Sistem Yang Diusulkan}

Dalam pembuatan sistem dan perancangan program dapat digambarkan dalam bentuk flowchart sehingga dapat mempermudah dalam melakukan dan merancang langkah-langkah atau proses dengan benar. Adapun bentuk dari flowchart keseluruhan dari sistem yang dibuat dapat dilihat pada gambar berikut : 


\section{Flowchart Home.}

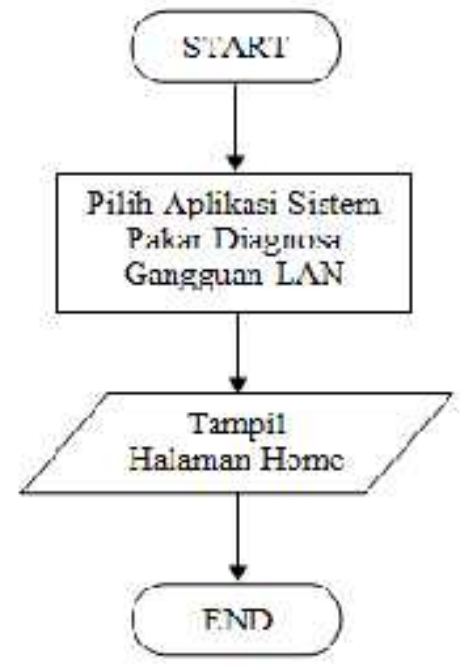

Gambar 4.9. Flowchart Home

Jalankan program Home, kemudian pilih salah satu menu yang terdapat pada halaman Home, yaitu terdiri dari : Diagnosa, Jenis Gangguan, Komponen LAN, Bantuan, Tentang Aplikasi.

\section{Flowchart Diagnosa.}

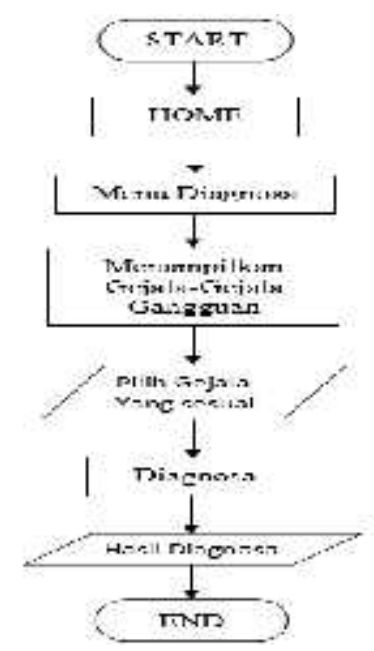

Gambar 4.10. Flowchart Diagnosa.

Pada halaman Home, pilih menu Diagnosa maka akan tampil menu Diagnosa. 


\section{Flowchart Jenis Gangguan.}

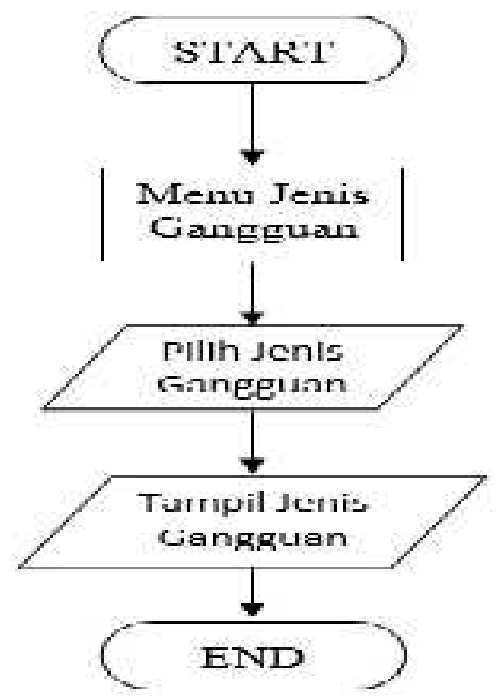

\section{Gambar 4.11. Flowchart Jenis Gangguan.}

Pada halaman Home, pilih menu Jenis Gangguan maka akan tampil menu Jenis Gangguan

\section{Flowchart Komponen LAN.}

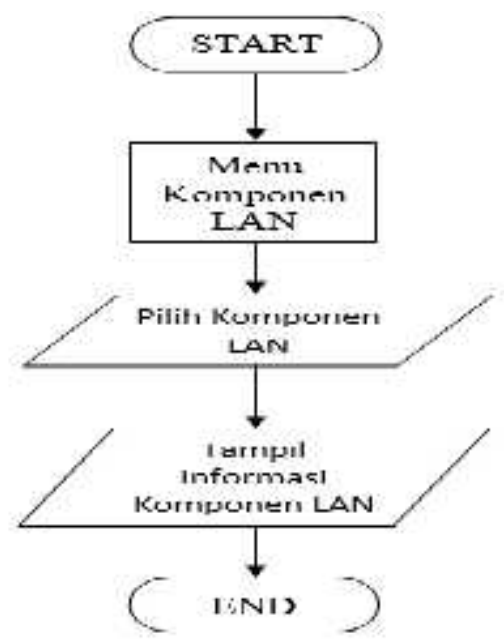

\section{Gambar 4.12. Flowchart Komponen LAN.}

Pada halaman Home, pilih menu Komponen LAN maka akan tampil menu Komponen LAN. 


\section{Flowchart Bantuan.}

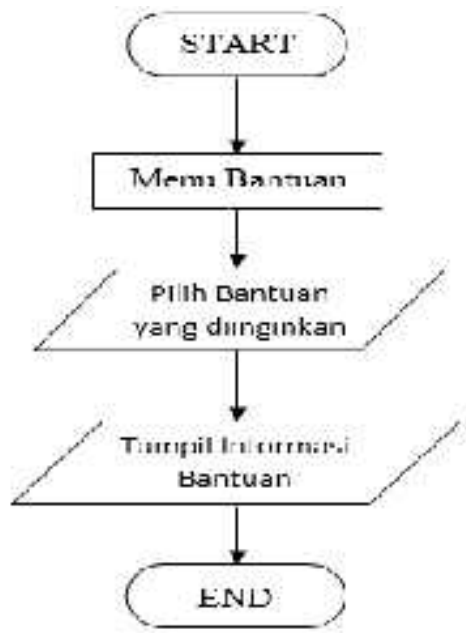

Gambar 4.13. Flowchart Bantuan.

Pada halaman Home, pilih menu Bantuan maka akan tampil menu Bantuan Aplikasi.

\section{Flowchart Tentang Aplikasi.}

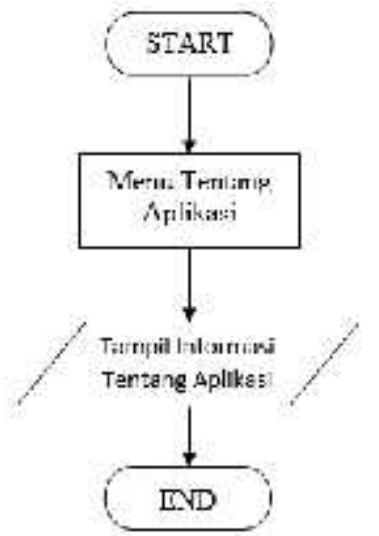

\section{Gambar 4.14. Flowchart Tentang Aplikasi.}

Pada halaman Home, pilih menu Tentang Aplikasi maka akan tampil menu Tentang Aplikasi.

\section{Rancangan Program}

HIPO (Hirarchy plus Input Process Output) yaitu alat bantu untuk membuat spesifikasi program yang merupakan struktur yang berisi diagram dimana di dalam program ini berisi input yang diproses dan menghasilkan output. Spesifikasi program menjelaskan mengenai cara penggunaan aplikasi program yang diusulkan. Visual Table Of Content (VTOC) adalah diagram yang menggambarkan hubungan dan fungsi pada sistem secara berjenjang, yaitu seperti dibawah ini: 


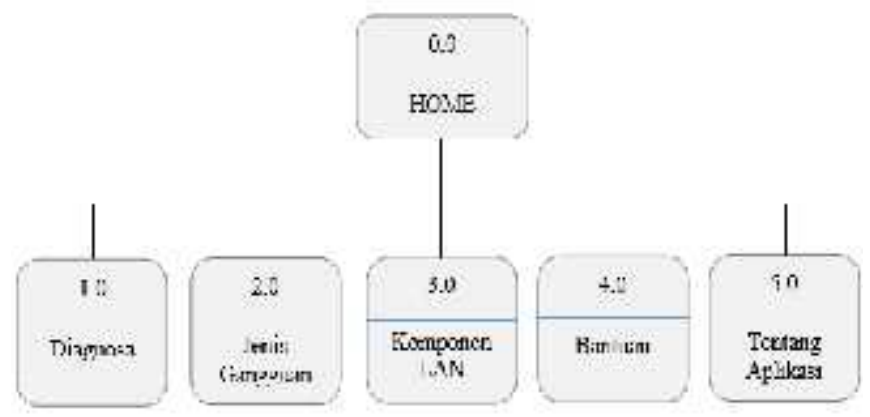

Gambar 4.15. Rancangan Program

Adapun spesifikasi program yang diusulkan yaitu sebagai berikut :

\section{Rancangan Prototype}

Berikut ini merupakan prototype atau model dasar dari perancangan Sistem Pakar diagnosa gangguan jaringan LAN.

1. Prototype tampilan home.

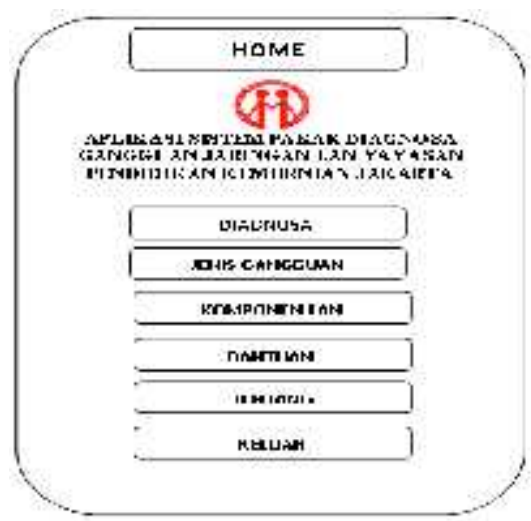

\section{Gambar 4.16. Prototype Tampilan Home.}

Fungsinya untuk menampilkan menu pilihan yang terdapat di dalam aplikasi.

2. Prototype menu diagnosa.

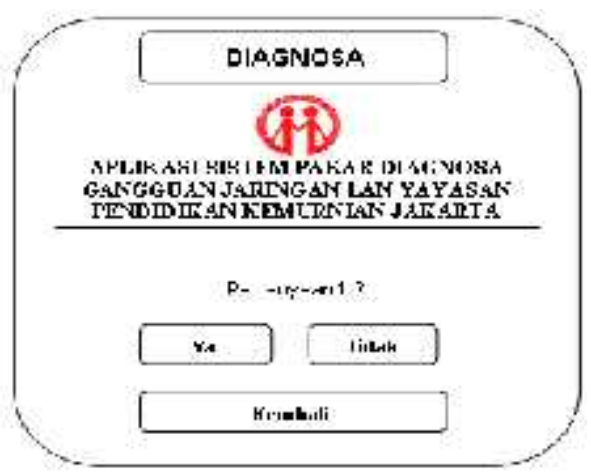

Gambar 4.17. Prototype Tampilan Diagnosa. 
Berfungsi untuk melakukan konsultasi diagnosa gangguan jaringan LAN

3. Prototype menu jenis gangguan.

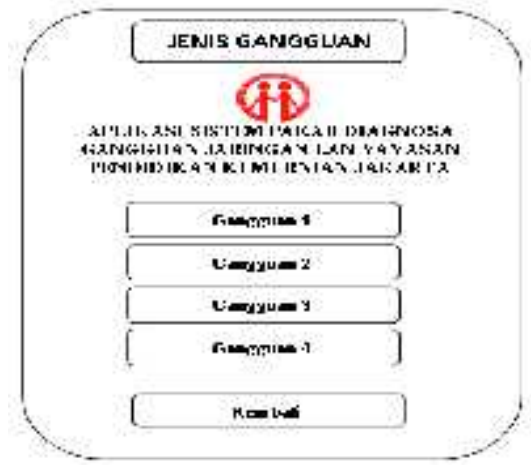

Gambar 4.18. Prototype Tampilan Jenis Gangguan.

Berfungsi untuk mengetahui informasi tentang jenis gangguan jaringan LAN.

4. Prototype menu informasi komponen jaringan LAN.

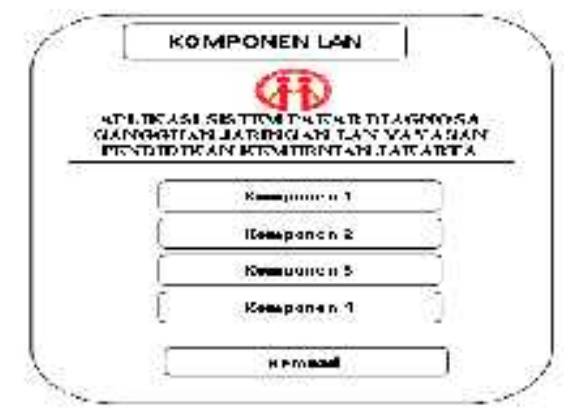

\section{Gambar 4.19. Prototype tampilan komponen jaringan LAN.}

Berfungsi untuk mengetahui informasi tentang komponen-komponen pada jaringan LAN.

5. Prototype menu bantuan

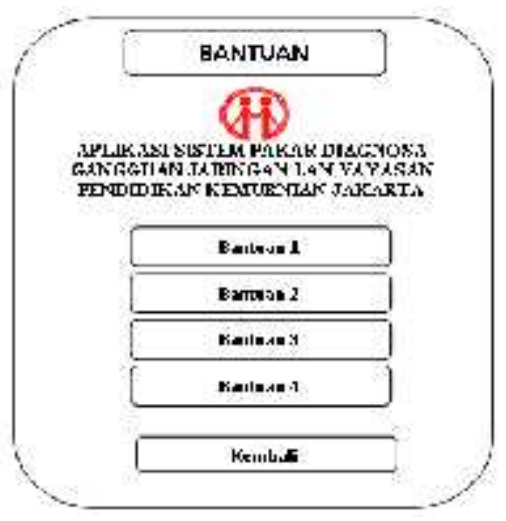

Gambar 4.20. Prototype menu bantuan 
Berfungsi untuk membantu dalam pengoperasian aplikasi sistem pakar ini sehingga user dapat dengan mudah menggunakan aplikasi ini.

6. Prototype menu tentang aplikasi.

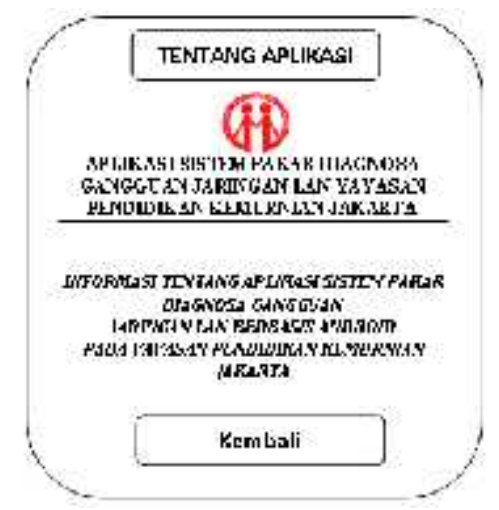

Gambar 4.21. Prototype tentang aplikasi.

Berfungsi untuk mengetahui informasi tentang aplikasi sistem pakar ini.

\section{KESIMPULAN}

Kesimpulan terhadap tujuan penelitian ini yaitu memudahkan user dalam menganalisa dan mengatasi masalah gangguan-gangguan yang terjadi pada jaringan LAN dengan lebih cepat sehingga tidak terlalu banyak waktu yang terbuang hanya untuk menunggu pihak IT datang untuk mengatasi masalah gangguan pada jaringan LAN, maka perlu perancangan dan pembuatan aplikasi sistem pakar diagnosa gangguan LAN yang berfungsi untuk memberikan informasi dan solusi terhadap gangguan LAN secara cepat dan tepat, serta mudah untuk dikembangkan lebih lanjut.

Adapun kesimpulan terhadap manfaat penelitian mengenai APLIKASI SISTEM PAKAR UNTUK MENDIAGNOSA GANGGUAN JARINGAN LAN BERBASIS ANDROID DI SEKOLAH KEMURNIAN JAKARTA, adalah sebagai berikut :

1. Dapat menambah pustaka ilmu dan wawasan bagi peneliti dan membantu peneliti untuk siap dan mampu dalam menyelesaikan masalah di kehidupan masyarakat melalui analisa dan kemajuan teknologi agar dapat diselesaikan dengan akurat, tepat dan efektif.

2. Bagi Pakar maupun User/Pengguna, yaitu Pakar dapat menggunakan sistem pakar ini sebagai knowledge assistant yang dapat digunakan kapan pun sebagai alat bantu untuk mempermudah pekerjaannya dan user dapat menggunakan aplikasi sistem pakar ini untuk mendiagnosa gangguan yang terjadi pada jaringan LAN dan mendapatkan solusi yang digunakan untuk mengatasi masalah gangguan tersebut.

\section{DAFTAR PUSTAKA}

[1] Daryanto. 2010. “Teknologi Jaringan Internet”. Bandung: Satu Nusa.

[2] Henderi. 2009. "Unified Modeling Language". Tangerang.

[3] Ipulhe. 2015. "Pengertian Aplikasi". http://www.ipulhe.com/pengertian-aplikasi/. Diakses tanggal 12 Juni 2016. 
[4] Iwan Sofana. 2012. "CISCO CCNA \& Jaringan Komputer," Bandung : Informatika. Jadibaru. 2015. "Pengenalan Android Studio". http://www.jadibaru.com/android/pengenalan-android-studio-2/. Diakses tanggal 19 Juni 2015.

[5] Jogiyanto, H.M. 2012. “Analisis dan Desain Sistem Informasi Pendekatan Terstruktur Teori dan Praktek Aplikasi Bisnis”. Yogyakarta: Andi.

[6] Kusrini. 2010. "Sistem Pakar Teori Dan Aplikasi”. Yogyakarta: Andi.

[7] Kusrini. 2009. “Menentukan Faktor Kepastian Pengguna Dengan Metode Kuantifikasi Pertanyaan”. Yogyakarta: Andi.

[8] Kurniawan, Helmi dan Iwan Fitrianto Rahmad. 2012. "Perancangan Sistem Pakar Untuk Mendeteksi Penyakit Pada Tanaman Cabe Dengan Metode Certainty Factor". Indonesia: Journal CCIT Vol.5 No.2-2012.

[9] Mulyanto, Agus. 2009. "Sistem Informasi Konsep \& Aplikasi". Yogyakarta: PustakaPelajar.

[10] Nugroho, Adi. 2010. “Analisis Perancangan Sistem Informasi dengan Metodologi Berorientasi Object”. Bandung: Informatika.

[11] Rahardja, Untung, Hidayati dan Mia Novalia. 2011. "Peningkatan Kinerja Distributed Database Melalui Metode DMQ Base Level”. Indonesia: Journal CCIT Vol.4 No.3 - Mei 2011

[13] Raharjo, Budi, Imam Heryanto dan Arif Haryono. 2010. "Mudah Belajar Java". Bandung: Informatika.

[14] Safaat, Nazruddin. 2012. "Pemrograman aplikasi mobile smartphone dan tablet PC berbasis Android". Bandung: Informatika.

[16] Sutabri, Tata. 2012. "Konsep Sistem Informasi”. Yogyakarta: Andi.

[17] Suyoto. 2004. "Intelegensi Buatan: Teori dan Pemrograman". Yogyakarta: Gava Media.

[18] Suyanto. 2007. "Artificial Intelligence (Searching, Reasoning, Planning, and Learning)". Bandung: Informatika.

[19] Tolle, Herman. 2008. "Pengantar Sistem Pakar”.

[20] Yakub. 2012. “Pengantar Sistem Informasi”. Yogyakarta: Graha Ilmu. 